\title{
Efek Twitter di Masa Pandemi COVID-19 pada Sikap dan Perilaku
}

\author{
Nurasyfina Rihhadatul'aisyi ${ }^{1}$, Saafira Muthmainnah ${ }^{2}$, Tazqya Wanda Putri ${ }^{3}$, \\ Humaira Phinata Zahra ${ }^{4}$, Faisal Tegar Febrian ${ }^{5}$ \\ 1,2,3,4,5Program Studi Ilmu Komunikasi, Fakultas Ilmu Komunikasi, Universitas Padjadjaran \\ Jl. Raya Bandung Sumedang KM.21, Hegarmanah, Kecamatan Jatinangor, \\ Kabupaten Sumedang, Jawa Barat 45363, Indonesia \\ Email: finanael@gmail.com ${ }^{1 *}$; smfiraa23@gmail.com²; tazqyawanda@gmail.com³ ${ }^{3}$ humaira23juni@gmail.com; \\ faisaltegarfebrian@gmail.com 5 \\ *Corresponding author
}

\begin{abstract}
The escalating amount of Twitter users during the era of COVID-19 pandemic indicates the importance of social media in distributing health information. Aside from its benefits, the high level of access on Twitter has the potential of causing distress in its audience regarding the information on COVID-19. Health messages found on Twitter aren't free from misinformation, which could lead to doubt and disregard on the audience's perspective around the pandemic. This issue is related to Cognitive Response Theory and Elaboration Likelihood Model Theory that explain how somebody's attitude and behavior is influenced by the message that they perceive. This research aims to find the relation between intensity of use and message credibility on students' health attitude and behavior during the COVID-19 pandemic. Quantitative method was used through a survey on 120 students of Faculty of Communication Studies, Padjadjaran University, using convenience sampling technique. The results of this research show that the intensity of use and message credibility variables do not have any relation with health attitude, but have a significant relation with students' change in health attitude. Keywords: COVID-19; Intensity of Twitter Usage; Message Credibility; Health Behavior; Health Attitude.
\end{abstract}

\begin{abstract}
Abstrak
Peningkatan pengguna Twitter secara pesat selama masa pandemi COVID-19 menandai pentingnya media sosial tersebut dalam proses penyebaran informasi kesehatan. Di samping manfaatnya, tingkat akses Twitter yang tinggi dapat menyebabkan masyarakat kewalahan dengan informasi seputar COVID-19. Pesan dalam Twitter juga tidak luput dari disinformasi yang dapat menimbulkan keraguan hingga pengabaian khalayak terhadap pandemi. Hal ini berhubungan dengan Teori Cognitive Response dan Teori Elaboration Likelihood Model (ELM) yang menyatakan bahwa sikap dan perilaku individu dapat dipengaruhi oleh pesan yang diterima individu tersebut. Penelitian ini bertujuan untuk menguji hubungan antara intensitas penggunaan dan kredibilitas pesan dalam Twitter terhadap sikap dan perilaku kesehatan mahasiswa di masa pandemi COVID-19. Penelitian menggunakan metode kuantitatif dengan survei terhadap 120 mahasiswa Fakultas Ilmu Komunikasi Universitas Padjadjaran menggunakan teknik convenience sampling. Penelitian ini menemukan bahwa variabel intensitas penggunaan dan kredibilitas pesan tidak memiliki hubungan terhadap perubahan perilaku kesehatan, namun berhubungan dengan perubahan sikap kesehatan mahasiswa. Kata kunci: COVID-19; Intensitas Twitter; Kredibilitas Pesan; Sikap Kesehatan; Perilaku Kesehatan.
\end{abstract}

\section{Pendahuluan}

Coronavirus disease (COVID-19), infeksi yang disebabkan virus Corona jenis baru bernama Severe Acute Respiratory Syndrome Coronavirus 2 (SARS-CoV-2), pertama kali ditemukan di Wuhan, Cina, pada akhir 2019 lalu (WHO, 2020b). Virus ini menular secara masif melalui droplet dari saliva orang yang terinfeksi yang tersembur ketika batuk atau bersin (WHO, 2020a). Pada Maret 2020, WHO resmi mendeklarasikan wabah ini sebagai pandemi (Indonesia.go.id,
2020). Per 1 September 2021 jumlah kasus positif dalam negeri mencapai 4.100.138 kasus, sedangkan total terinfeksi di seluruh dunia mencapai 217.947.269 kasus (Bramasta, 2021).

Guna menghadapi perubahan tatanan sosial akibat pandemi, serangkaian protokol kesehatan diterapkan (WHO, 2020a). Kondisi ini dikenal sebagai new normal atau Adaptasi Kebiasaan Baru (AKB). Adaptasi Kebiasaan Baru adalah upaya pembiasaan perilaku hidup bersih dan sehat dengan rutin mencuci tangan pakai sabun 
minimal 20 detik, memakai masker ketika keluar rumah, menjaga jarak aman minimal 1 meter, serta menghindari kerumunan (Kementerian Kesehatan Republik Indonesia, 2020). Sosialisasi protokol dan pemberian informasi kesehatan secara cukup dapat membantu masyarakat dalam menentukan sikap dan perilaku kesehatannya (Komite Penanganan COVID-19 dan Pemulihan Ekonomi Nasional, 2020; Maragakis, 2020).

Para peneliti melaporkan adanya peran media sosial sebagai sarana efektif dalam memenuhi kebutuhan informasi kesehatan publik (AlDmour et al., 2020). Pernyataan ini didukung dengan sebuah penelitian yang mengungkapkan bahwa media sosial menjadi sumber informasi yang paling sering digunakan masyarakat selama pandemi COVID-19 (Gupta et al., 2020). Hal ini juga dibuktikan oleh data dari Twitter yang menunjukkan kenaikan pesat jumlah pengguna dari semula 166 juta pada tahun 2020 menjadi 199 juta pengguna aktif harian di tahun 2021 (VOI Indonesia, 2021). Berdasarkan laporan We Are Social dan Hootsuite pada Januari 2021, pengguna media sosial di Indonesia didominasi oleh usia 25-34 tahun $(34,1 \%)$ dan 18-24 tahun (30,7\%). Penelitian (Wang et al., 2011), mengungkapkan mahasiswa memiliki ketertarikan yang besar terhadap media sosial. Mayoritas mengakses media sosial 6-8 jam dalam sehari. Media sosial dibuktikan menjadi saluran utama yang paling tepat untuk memberikan informasi terkait kesehatan kepada mahasiswa (Prybutok \& Ryan, 2015; Shi et al., 2018). Belum ada penelitian formal yang dilakukan mengenai popularitas media sosial terhadap kesehatan mahasiswa secara nasional (Perrault et al., 2019). Informasi kesehatan di media sosial berperan penting dalam meningkatkan kesadaran publik mengenai penyakit beserta gejalanya, dan mengenai tindakan pencegahan yang harus dilakukan (karantina, vaksinasi) (Depoux et al., 2020). Sebagian besar juga masih berfokus pada media sosial seperti Whatsapp, Instagram, dan Youtube, meskipun Twitter memiliki peran besar dalam menyebarkan informasi kesehatan (Rosini \& Nurningsih, 2018).
Intensitas informasi COVID-19 di media sosial yang berlebihan menyebabkan sebagian pihak khawatir akan dampaknya terhadap kesehatan mental dan imunitas publik (Dzulfaroh, 2020). Penelitian sebelumnya menemukan tingginya intensitas paparan media memiliki kaitan dengan berbagai masalah kesehatan mental di tengah pandemi (Gao et al., 2020). Tidak hanya itu, berita mengenai penyakit menular juga berpotensi menyebabkan kepanikan massal (Wheaton et al., 2021). Reaksi dan tanggapan publik terhadap informasi dalam media sosial tersebut juga dapat mengarah pada peningkatan kecemasan (Strekalova, 2017). Informasi dalam media sosial juga tidak selalu akurat serta menyebabkan disinformasi (Gupta et al., 2020). Disinformasi dapat memengaruhi pengambilan keputusan dan tindakan kesehatan di tengah pandemi. Informasi resmi dan akurat terkait COVID-19dapatmencegahtimbulnyakepanikan, kecemasan, dan disinformasi (Lancet, 2020).

Di sisi lain, media sosial dibutuhkan publik untuk mengakses informasi kesehatan (Kor et al., 2021). Informasi kesehatan di media sosial berperan penting dalam meningkatkan kesadaran publik mengenai penyakit beserta gejalanya, dan mengenai tindakan pencegahan yang harus dilakukan (karantina, vaksinasi) (Depoux et al., 2020). Media sosial juga memfasilitasi publik untuk bertanya langsung dan melihat tanggapan pihak berwajib dan para ahli terkait COVID-19 (Venegas-Vera et al., 2020).

Berdasarkan pernyataan-pernyataan sebelumnya, penggunaan media sosial mengalami peningkatan yang pesat selama masa pandemi COVID-19 dan berimplikasi terhadap penyebaran disinformasi. Kedua hal tersebut dapat memengaruhi sikap dan perilaku khalayak selama pandemi. Hal ini kemudian berkorelasi dengan Teori Cognitive Response yang dikemukakan oleh Aaker dan Myers, yang menjelaskan tentang proses yang dialami individu dalam melalui perubahan sikap, serta teori Elaboration Likelihood Model yang digagas Petty dan Cacioppo tahun 1986 (Van 
Lange et al., 2011), yang menyatakan bahwa kredibilitas pesan dapat memengaruhi sikap khalayak melalui rute sentral dan periferal. Penelitian ini juga menggunakan Teori Planned Behavior milik Icek Ajzen, yang menjelaskan bahwa terdapat tiga komponen utama yang membentuk intensi perilaku seseorang, yaitu sikap, norma subjektif, serta kontrol perilaku persepsi (Ajzen, 2020). Penelitian-penelitian terdahulu telah membahas hubungan antara informasi kesehatan di media sosial dengan sikap dan perilaku publik, namun sebagian besar masih berfokus pada media sosial seperti Whatsapp, Instagram, dan Youtube, meskipun Twitter memiliki peran besar dalam menyebarkan informasi kesehatan (Rosini \& Nurningsih, 2018). Penelitian ini berusaha mengeksplorasi hubungan antara intensitas dan kredibilitas pesan dalam Twitter terhadap sikap dan perilaku kesehatan mahasiswa selaku generasi muda.

\section{Efek Media Sosial di Masa Pandemi}

Kementerian Komunikasi dan Informatika Republik Indonesia melaporkan adanya peningkatan penggunaan internet di masa pandemi mencapai 30 hingga 40 persen (Kementerian Komunikasi dan Informatika, 2020). Peningkatan ini menyusul diterapkannya kebijakan bekerja dan belajar dari rumah guna mencegah penyebaran COVID-19. Dampaknya sebagian besar orang mencari dan menerima informasi kesehatan secara online, salah satunya dari media sosial (Chen et al., 2018). Media sosial adalah media baru yang berfungsi sebagai sarana berbagi, berkumpul, dan berkomunikasi, sekaligus sumber informasi, termasuk informasi kesehatan (McGowan et al., 2012; Nasrullah, 2015). Sejumlah penelitian telah menemukan adanya potensi media sosial sebagai platform komunikasi kesehatan publik (Al-Dmour et al., 2020).

Di masa pandemi, media sosial dapat menjadi alat efektif dalam menyebarkan informasi kesehatan secara real-time tentang status penyakit dan memberi saran yang tepat pada publik tentang cara pencegahan penyakit (Prybutok \& Ryan, 2015). Seperti yang terjadi pada awal masa pandemi, masyarakat secara masif mencari informasi seputar virus di media sosial. Tercatat, 19 juta unggahan mengenai COVID-19 dibagikan dalam kurun waktu 24 jam (Ahmad \& Murad, 2020). Media sosial dapat memenuhi tuntutan kebutuhan informasi yang terus berubah dan selalu baru di tengah situasi krisis (Gottlieb \& Dyer, 2020), seperti pandemi saat ini.

Di balik banyaknya keuntungan menggunakan media sosial pada masa pandemi, terdapat pula ancaman negatif media sosial seperti disinformasi, ketidakakuratan pesan, kepanikan, konspirasi, hingga propaganda (Tagliabue et al., 2020). Kementerian Komunikasi dan Informatika (Kominfo) menyebutkan sedikitnya terdapat 1.387 pesan hoaks sepanjang pandemi COVID-19 di Indonesia (Aditya, 2021). Tingginya intensitas hoaks turut dipengaruhi pendapat figur publik, politikus, dokter, dan sejumlah non-medical professionals yang tidak bersandar pada sains (Bernasconi, 2020; Tagliabue et al., 2020). Hal ini sehubungan dengan pernyataan Bechmann dan Lomborg pada tahun 2013 yang mengungkapkan bahwa media sosial merupakan platform daring yang konten di dalamnya tidak dibuat dan disebarluaskan oleh perusahaan maupun organisasi media, melainkan bergantung pada struktur berbagi internet yang terdesentralisasi (Stoycheff et al., 2017).

World Health Organization (WHO) telah menyatakan perlawanan, tidak hanya terhadap pandemi, melainkan juga terhadap 'infodemik' (Ahmad \& Murad, 2020), istilah untuk menggambarkan tingginya intensitas informasi COVID-19 dalam media. Hal ini seiring dengan laporan WHO yang menyatakan bahwa percakapan terkait pandemi di media sosial Twitter telah mencapai jumlah maksimum, yaitu 548,152,410 percakapan dalam satu hari (Brooks, 2020). Laporan TalkWalker dari New York, AS, juga menyebutkan 40.2 juta informasi 
COVID-19 telah diakses dari media sosial sepanjang 12-18 Mei 2020 (Gottlieb \& Dyer, 2020). Kebanjiran informasi ini menyebabkan publik kewalahan serta tidak memiliki cukup waktu untuk memahami informasi yang benar (Tagliabue et al., 2020), sehingga berpotensi menimbulkan hoaks. Orang melakukan verifikasi terlebih dahulu pesan yang diterima merupakan langkah paling efektif untuk menangkal kepanikan dan disinformasi (Lancet, 2020). Ini menjadi penting karena penggunaan media sosial sebagai sumber informasi dapat memengaruhi kecenderungan sikap dan perilaku kesehatan seseorang (Perrault et al., 2019).

Sikap adalah suatu kegiatan mengevaluasi objek, tempat, atau masalah yang memengaruhi pikiran dan tindakan seseorang. Komponen sikap yaitu kepastian, emosi, dan intensi berperilaku. Sikap bukanlah perilaku, namun dapat memprediksi perilaku seseorang (Perloff, 2017). Menurut Cacioppo dan Petty (Alibali et al., 2019) terpaan berulang kali dapat meningkatkan pengetahuan dan pemahaman individu terhadap suatu pesan, yang mengarah pada perasaan setuju atau tidak setuju. Sikap juga dipengaruhi oleh kebutuhan kognisi atau need for cognition (NC). Cacioppo dkk. menjabarkan need for cognition (NC) sebagai individu yang senang terlibat aktivitas yang mengasah pola berpikir (Farida et al., 2018) yang kemudian disebut sebagai orang dengan kebutuhan kognisi tinggi. Sikap individu dalam kelompok ini cenderung dipengaruhi oleh informasi yang berkualitas. Sebaliknya, sikap individu dengan kebutuhan kognisi rendah cenderung dipengaruhi oleh informasi yang lebih sederhana.

Sementara itu, studi sebelumnya telah mengungkapkan adanya pengaruh kampanye kesehatan di media sosial terhadap perubahan perilaku individu secara positif dan mencegah perubahan perilaku negatif. Literatur lain juga menemukan adanya peran media sosial dalam penyebaran informasi kesehatan yang dapat menyebabkan perubahan perilaku (AlDmour et al., 2020). Berdasarkan uraian tersebut, pendekatan yang cermat dan objektif sangat diperlukan dalam menginterpretasi data dan temuan ilmiah di media sosial guna menentukan sikap dan perilaku kesehatan yang tepat dalam menghadapi pandemi COVID-19 (Venegas-Vera et al., 2020).

\section{Intensitas Penggunaan Twitter di Masa Pandemi}

Penelitian sebelumnya telah menemukan bahwa konten pada Twitter berguna untuk mendeteksi wabah penyakit, termasuk tandatanda awal terjadinya pandemi (Gharavi et al., 2020; St Louis dan Zorlu, 2012). Prediksi mengenai pandemi dalam Twitter bersifat hampir tepat waktu karena disebabkan faktor birokrasi pemerintah, tes pengembangan, tes pemrosesan waktu, dan waktu melakukan pelaporan, sehingga Twitter dapat digunakan sebagai sistem peringatan dini untuk meningkatkan kesadaran publik (Gharavi et al., 2020; Rong et al., 2020).

Penyebaran COVID-19 secara global telah menjadikan Twitter sebagai salah satu alat yang paling sering digunakan untuk memublikasikan dan mendapatkan informasi di dunia (Seddighi et al., 2021). Terdapat diskusi mengenai penyebaran informasi di Twitter dan dampaknya dalam memperoleh informasi kesehatan (Sciences, 2020). Diskusi tersebut mengemukakan bahwa peringatan dini menjadi salah satu kegunaan Twitter dalam keadaan yang darurat, utamanya pandemi. Berdasarkan pernyataan-pernyataan sebelumnya, telah terbukti bahwa terdapat berbagai penelitian yang mengindikasikan efek positif Twitter terhadap perilaku intervensi dan perilaku kesehatan. Meski demikian, belum banyak penelitian lainnya yang membahas intensitas media sosial secara spesifik, maupun hubungannya dengan sikap dan perilaku kesehatan di masa pandemi. 
Intensitas penggunaan media sosial dapat didefinisikan sebagai sejauh mana pengguna terlibat secara aktif dalam jejaring sosial (Stojanovic et al., 2018). Dalam kata lain, intensitas dapat diartikan sebagai frekuensi penggunaan media sosial (Boer et al., 2021). Ketika mengukur intensitas penggunaan media sosial, penelitian-penelitian sebelumnya menggunakan berbagai metode pengukuran. Salah satu pengukuran intensitas penggunaan media sosial dapat dilihat dalam penelitian (Wirtz et al., 2017) yang meneliti Facebook. Intensitas penggunaan Facebook diukur berdasarkan rata-rata waktu per jam yang dihabiskan untuk menggunakan Facebook, serta rata-rata pengumuman yang diunggah per minggu. Penelitian lainnya yang dilakukan oleh (Petrocchi et al., 2015) menemukan bahwa intensitas penggunaan Twitter diukur melalui skala Likert yang terdiri dari delapan pertanyaan seputar durasi penggunaan Twitter, jumlah teman di Twitter, dan sikap serta perasaan sebagai komunitas pengguna Twitter.

Selama masa pandemi, intensitas penggunaan Twitter telah mengalami peningkatan. Pada akhir tahun 2019, Twitter memiliki pengguna aktif sejumlah 152 juta per hari. Pada bulan April 2020, tepat satu bulan setelah COVID-19 dinyatakan sebagai pandemi oleh World Health Organization, pengguna Twitter meningkat menjadi 166 juta pengguna per harinya. Satu tahun setelah pandemi dimulai, ditemukan 199 juta pengguna aktif Twitter per hari pada tahun 2021 (VOI Indonesia, 2021; Washington Post, 2020). Bersumber dari statistik laporan Statista 19 Februari2020,tercatatbahwamayoritas pengguna Twitter berusia 25-34 tahun sebesar 35.6\% dan diikuti oleh pengguna yang berusia 18-24 tahun sebesar 30.3\%. Usia 18-24 tahun termasuk dalam rentang umur mahasiswa (Nurrezki \& Irawan, 2020) dan peran Twitter sendiri bagi mahasiswa dapat memenuhi beberapa hal, yaitu informasi, interaksi, integrasi sosial, dan hiburan.

\section{Kredibilitas Pesan di Twitter dengan Sikap dan Perilaku Kesehatan}

Media sosial memungkinan adanya penjangkauan informasi yang salah oleh khalayak yang luas dan masyarakat, sehingga dapat mengarah pada konsekuensi yang merugikan (Cook et al., 2017). Tidak semua informasi yang terdapat di Twitter, termasuk informasi kesehatan mengenai COVID-19, bersifat akurat (Ali et al., 2021). Salah satu penelitian menemukan bahwa $25 \%$ dari pesan kesehatan mengenai pandemi COVID-19 di Twitter yang diteliti mengandung informasi yang salah, dan $17 \%$ menunjukkan informasi yang tidak terverifikasi kebenarannya (Kouzy et al., 2020). Informasi yang salah atau menyesatkan disebut juga sebagai disinformasi (Cook et al., 2017; Zhang et al., 2018).

Dalam ranah kesehatan, penyebaran disinformasi menuntun kepada perubahan sikap sepertiketakutandankeraguan, dimanaperubahan sikap yang berlangsung terus menerus ini dapat mengarah kepada perubahan perilaku seperti pengabaian pembatasan sosial oleh masyarakat, juga kekeliruan diagnosa kesehatan (Rosenberg et al., 2020). Hal ini kemudian membuat para peneliti mulai mengembangkan strategi pencegahan penyebaran disinformasi melalui Twitter (Pennycook et al., 2020). Fenomena disinformasi dipengaruhi oleh sifat tentatif informasi ilmiah, yang kemudian menciptakan tantangan baru dalam penilaian kredibilitas (Bromme \& Goldman, 2014; Flemming et al., 2017). Di lingkungan media saat ini, dimana khalayak menerima sejumlah besar pesan, skala yang secara eksklusif mengukur kredibilitas pesan akan berguna dalam berbagai situasi. Penelitian yang berfokus pada pembangunan skala untuk mengukur kredibilitas pesan dapat dinilai melalui kebenaran, keaslian, dan kepercayaannya (Appelman \& Sundar, 2016).

Berdasarkan hal-hal yang telah dipaparkan, peneliti kemudian merumuskan pertanyaan dan hipotesis penelitian, yaitu: 
H0:Tidak terdapat hubungan antara intensitas mengakses Twitter terhadap kesehatan mahasiswa.

H1:Terdapat hubungan antara intensitas mengakses Twitter terhadap sikap kesehatan mahasiswa. $\mathrm{H} 2$ : Terdapat hubungan antara kredibilitas pesan di Twitter terhadap sikap kesehatan mahasiswa.

H3:Terdapat hubungan antara intensitas mengakses Twitter terhadap perilaku kesehatan mahasiswa. H4:Terdapat hubungan antara kredibilitas pesan di Twitter terhadap perilaku kesehatan mahasiswa. Berdasarkan uraian-uraian di atas, diketahui terdapat sejumlah faktor yang dapat memengaruhi perubahan sikap dan perilaku. Belum ditemukan penelitian yang secara spesifik membahas faktor intensitas penggunaan dan kredibilitas pesan di Twitter terhadap perubahan sikap dan perilaku masyarakat. Penelitian ini berupaya menjadi pembaharuan dari sejumlah penelitian sebelumnya, dengan tujuan menemukan hubungan antara intensitas penggunaan Twitter dan kredibilitas pesan di Twitter terhadap sikap dan perilaku kesehatan pengguna yang dalam penelitian ini merupakan kalangan mahasiswa.

\section{Metode Penelitian}

Penelitian dilakukan dengan menggunakan metode kuantitatif, dengan tujuan untuk mengetahui hubungan antara variabel independen (X) yaitu Terpaan dan Kredibilitas Media Sosial Twitter dengan variabel dependen (Y), yaitu Sikap dan Perilaku Kesehatan. Penelitian ini bersifat survei non-eksperimental.

Populasi penelitian adalah mahasiswa aktif Fakultas Ilmu Komunikasi Universitas Padjadjaran dari 7 prodi, dengan rentang usia 18-20 tahun. Teknik sampling yang digunakan dalam penelitian ini adalah non-probability sampling dengan metode pengambilan sampel convenience sampling. Jumlah sampel ditentukan melalui aplikasi $g$-power dengan jenis uji-t atau t-test untuk menguji apabila ada kemungkinan kesalahan data. Perhitungan jumlah sampel menggunakan $\mathrm{r}=0.35$, error probability $=5 \%$, dan power $=95 \%$ atau 0.95 . Dari perhitungan tersebut, ditemukan bahwa target jumlah sampel yang diambil sebesar 79 responden.

Partisipan yang menjadi responden data merupakan pengguna media sosial Twitter yang berjumlah 120 responden dan berstatus sebagai mahasiswa aktif Fakultas Ilmu Komunikasi Universitas Padjadjaran dengan rentang usia 17-22 tahun yang berasal dari Prodi Ilmu Komunikasi (40\%), Televisi dan Film (16,7\%), Ilmu Perpustakaan (10,8\%), Jurnalistik (10,8\%), Manajemen Produksi Media (10\%), Manajemen Komunikasi (8,3\%) dan Hubungan Masyarakat $(3,4 \%)$ yang terdiri dari angkatan 2020 (14,2\%), 2019 (69,2\%), dan 2018 (16,7\%).

Data dikumpulkan dengan menyebarkan kuesioner elektronik atau daring Google Form yang disebarluaskan pada tanggal 7-11 November 2020 kepada seluruh mahasiswa Fakultas Ilmu Komunikasi Universitas Padjadjaran. Sehingga didapatkan data sebanyak 120 responden yang mengisi kuesioner.

Terdapat empat alat pengukuran yang digunakan dalam penelitian. Pertama, indikator Intensitas Penggunaan Twitter digunakan untuk mengetahui frekuensi dan durasi responden dalam mengakses media sosial Twitter dengan menggunakan pertanyaan terbuka (variabel X; item 1-2). Indikator ini juga ditujukan untuk meneliti atensi audiens terhadap pemaparan konten kesehatan yang diakses melalui Twitter dengan menggunakan skala ordinal (variabel $\mathrm{X}$; item 3-6). Kedua, indikator Kredibilitas Twitter Sebagai Sumber Informasi Kesehatan digunakan untuk mengukur persepsi responden sebagai audiens Twitter terhadap kredibilitas pesan-pesan yang disampaikan di media sosial terkait, khususnya dalam konten berisi informasi kesehatan dan COVID-19 dengan 
tingkatan tertentu (variabel X; item 7-10). Ketiga, Sikap terhadap Kesehatan menjadi indikator yang meneliti pengaruh informasi kesehatan di internet, khususnya Twitter, terhadap persepsi dan pengambilan keputusan audiens terkait kesehatan (variabel Y; item 1-4). Keempat, indikator Perilaku Kesehatan digunakan untuk mengukur sejauh mana sikap terhadap kesehatan dapat berpengaruh terhadap implementasi perilaku kesehatan audiens Twitter.

Analisis data yang digunakan dalam penelitian ini adalah analisis deskriptif dan statistika inferensia. Hipotesis diuji dengan menggunakan Uji Korelasi Pearson's dalam upaya menemukan hubungan terpaan media sosial Twitter dengan sikap dan perilaku kesehatan mahasiswa. Uji dilakukan dengan menggunakan aplikasi SPSS versi 22.0. Uji validitas dan reliabilitas turut dilakukan untuk mengukur akurasi alat ukur yang digunakan sebelum kuesioner disebarkan.

Uji validitas dilakukan untuk menguji seberapa akurat item-item pernyataan dapat mengukur realitas. Adapun item pernyataan dikatakan valid ketika nilai $\mathrm{r}$ hitung $>\mathrm{r}$ tabel, mengacu pada taraf signifikansi 5\% dalam perhitungan $r$ Product Moment. Seluruh item pernyataan dalam uji validitas yang telah dipaparkan di atas memiliki nilai $>0,361$ yang merupakan nilai $r$ tabel dari $\mathrm{N}=30$, maka dapat disimpulkan bahwa seluruh item pernyataan bersifat valid. Jumlah 30 responden didapatkan dari kuesioner trial yang disebarkan sebelum kuesioner perolehan data disebarkan, dengan menggunakan setiap item pernyataan yang sama.

Uji reliabilitas dilakukan untuk menguji seberapa konsisten alat ukur yang digunakan dalam mengukur variabel, yang mengacu pada parameter koefisien Guilford. Berdasarkan uji reliabilitas yang telah dilakukan, dapat diketahui bahwa nilai Cronbach's Alpha pada setiap item menunjukkan interval 0.70 - 0.90, sehingga dapat disimpulkan bahwa alat ukur yang digunakan bersifat reliabel.
Hasil Penelitian dan Pembahasan Hasil dan Analisis Pengujian Intensitas (X1) terhadap Sikap (Y1)

Hipotesis dasar (H0) dalam penelitian menduga bahwa tidak terdapat hubungan antara intensitas mengakses Twitter terhadap sikap kesehatan mahasiswa, sementara hipotesis pertama (H1) menduga adanya hubungan antara intensitas mengakses Twitter terhadap sikap kesehatan mahasiswa. Penelitian ini menggunakan pengujianhipotesis yang dilakukan dengan uji korelasi Pearson Product Moment menggunakan IBM Statistical Package for the Social Sciences versi 22.0 (IBM SPSS 22) yang menghubungkan antara variabel Intensitas (X1) terhadap Sikap (Y1). Penolakan atau penerimaan hipotesis mengacu pada ketentuan signifikansi (sig) $<\alpha=0.05$ atau 0.01 , maka $\mathrm{H} 0$ ditolak dan $\mathrm{H} 1$ diterima, sedangkan jika signifikansi ( $\mathrm{sig})>\alpha=$ 0.05 atau 0.01 , maka $\mathrm{H} 0$ diterima dan $\mathrm{H} 1$ ditolak.

Hasil dari uji yang dilakukan menunjukkan adanya koefisien korelasi sebesar $r=0.287$ pada pengujian dua sisi dengan taraf signifikansi $p=0.01$, sehingga terdapat cukup bukti untuk menyatakan bahwa terdapat hubungan antara intensitas mengakses Twitter terhadap perubahan sikap kesehatan mahasiswa selama masa pandemi COVID-19. H0 ditolak, H1 diterima.

Berdasarkan uji distribusi frekuensi variabel Intensitas (X1) dengan Sikap (Y1), ditemukan bahwa sebanyak 51 responden diketahui menggunakan Twitter paling sedikit 7 kali dalam satu minggu (42,5\%) dan 100 responden mengakses Twitter selama 1-3 jam dalam sehari (83,3\%). Sebagian besar responden menggunakan Twitter untuk mendapatkan berita dan informasi mengenai COVID-19. Responden menemukan beragam topik kesehatan di antaranya seputar pandemi COVID-19 di Twitter dan memberi perhatian khusus terhadap topik tersebut.

Hasil analisis data responden mengenai sikap kesehatan menunjukkan bahwa 89,2\% responden menyesuaikan persepsinya mengenai kesehatan setelah menerima sejumlah informasi 
Tabel 1 Analisis Uji Pearson Intensitas (X1) terhadap Sikap (Y1)

\begin{tabular}{ccc}
\hline \multicolumn{2}{c}{ Correlation } & Sikap \\
\hline Intensitas & Pearson & $.287^{* *}$ \\
& Correlation & \\
& Sig. (2-tailed) & .001 \\
$\mathrm{~N}$ & 120 \\
\hline$* *$. Correlation is significant at the 0.01 level (2-tailed
\end{tabular}

Sumber: Hasil Olah Data Penelitian (2020)

dari Twitter. Persepsi tersebut selanjutnya digunakan sebagai dasar pengambilan keputusan dan perubahan nilai atau cara pandang responden terhadap suatu fenomena kesehatan. Responden menganggap, informasi yang didapatkan di media sosial amat penting untuk menjadi referensi dan pertimbangan dalam pengambilan keputusan mengenai kesehatan. Tabel 1 menunjukkan bahwa terdapat hubungan antara intensitas penggunaan Twitter dengan sikap kesehatan mahasiswa.

\section{Hasil dan Analisis Pengujian Kredibilitas (X2) terhadap Sikap (Y1)}

Hipotesis dasar (H0) dalam penelitian menduga bahwa tidak terdapat hubungan antara kredibilitas pesan di Twitter terhadap sikap kesehatan mahasiswa, sementara hipotesis kedua (H2) menduga terdapat hubungan antara kredibilitas pesan di Twitter terhadap sikap kesehatan mahasiswa.

Dengan koefisien korelasi sebesar $r=0.405$ pada taraf signifikansi $p=0.01$ terdapat cukup buktiuntukmenyatakan bahwa terdapathubungan antara kredibilitas pesan di Twitter terhadap sikap kesehatan mahasiswa. H0 ditolak, H2 diterima.

Sebanyak 55,8\% responden percaya dengan kebenaran informasi kesehatan di dalam Twitter. Meskipun sebagian besar responden setuju bahwa informasi yang dimuat dalam Twitter merupakan fakta, sebagian responden juga berpendapat bahwa masih kurangnya bukti yang disajikan dalam informasi kesehatan tersebut. Tabel 2 menunjukkan bahwa kredibilitas pesan memengaruhi sikap kesehatan dari mahasiswa.
Tabel 2 Analisis Uji Pearson Kredibilitas (X2) terhadap Sikap (Y1)

\begin{tabular}{ccc}
\hline \multicolumn{2}{c}{ Correlation } & Sikap \\
\hline Kredibilitas & Pearson & $.405^{* *}$ \\
& Correlation & \\
Sig. (2-tailed) & .000 \\
$\mathrm{~N}$ & 120 \\
\hline **. Correlation is significant at the 0.01 level (2-tailed) \\
Sumber: Hasil Olah Data Penelitian (2020)
\end{tabular}

\section{Hasil dan Analisis Pengujian Intensitas (X1) terhadap Perilaku (Y2)}

Hipotesis dasar pada pengujian Intensitas terhadap Perilaku (H0) menduga bahwa tidak terdapat hubungan antara intensitas mengakses Twitter terhadap perubahan perilaku kesehatan mahasiswa, dengan hipotesis ketiga (H3) yang menduga bahwa terdapat hubungan antara intensitas mengakses Twitter terhadap perubahan perilaku kesehatan mahasiswa sebagaimana yang dijelaskan pada Tabel 3 .

Pada tabel 3, variabel perilaku dan intensitas memiliki koefisien korelasi yang bernilai $r=$ 0.082 . Nilai signifikansi $p=0,374$. Karenanya, tidak terdapat hubungan antara perilaku dan intensitas karena memiliki Sig. (2-tailed) lebih besar dari 0,05 atau 0,01. H0 diterima, H3 ditolak.

Dalam penelitian ini, sebanyak 95\% responden mematuhi protokol kesehatan pada masa pandemi COVID-19, sehingga populasi terukur memiliki tingkat perilaku kesehatan yang tinggi. Di samping itu, terdapat 83,3\% responden yang menggunakan Twitter selama 1-3 jam setiap hari. Kedua variabel terukur memiliki nilai yang tinggi secara individu, penelitian ini membuktikan bahwa keduanya tidak berhubungan atau memiliki korelasi.

\section{Hasil dan Analisis Pengujian Kredibilitas (X2) terhadap Perilaku (Y2)}

Hipotesis dasar (H0) dalam penelitian mengenai kredibilitas terhadap perilaku menduga adanya hubungan antara kredibilitas pesan di Twitter terhadap perilaku kesehatan mahasiswa, sementara hipotesis keempat dalam 
Tabel 3 Analisis Uji Pearson Intensitas (X1) terhadap Perilaku (Y2)

\begin{tabular}{ccc}
\hline \multicolumn{2}{c}{ Correlation } & Perilaku \\
\hline Intensitas & Pearson & .082 \\
& Correlation & \\
& Sig. (2-tailed) & .374 \\
& $\mathrm{~N}$ & 120 \\
\hline Sumber: Hasil Olah Data Penelitian (2020)
\end{tabular}

penelitian (H4) diduga terdapat hubungan antara kredibilitas pesan di Twitter terhadap perilaku kesehatan mahasiswa. Tabel 4 menjelaskan bahwa variabel kredibilitas dan perilaku memiliki nilai koefisien korelasi yang mendekati 0 . Menurut kriteria tingkat kekuatan korelasi, hal ini menunjukkan bahwa hubungan kedua variabel sangat lemah. Kekuatan korelasi ini hanya signifikan apabila nilai Sig. (2-tailed) lebih kecil dari 0,05 atau 0,01 . Dengan nilai signifikansi sebesar $p=0,799$, dapat dinyatakan bahwa tidak terdapat hubungan antara variabel kredibilitas pesan di Twitter terhadap variabel perilaku kesehatan mahasiswa. H4 ditolak, H0 diterima.

Petty dan Cacioppo menjelaskan bahwa teori Elaboration Likelihood Modelkredibilitas pesan dapat mempengaruhi sikap khalayak melalui rute sentral dan periferal (Petty \& Briñol, 2012). Apabila pesan berlangsung terus menerus, hal ini berkemungkinan untuk memengaruhi perubahan perilaku secara tidak langsung, namun persepsi khalayak terhadap kredibilitas dan kapabilitas media sosial bervariasi (Zhang, et al., 2019). Terutama pada media sosial, pesan disampaikan oleh berbagai sumber dengan latar belakang yang kurang jelas. Dengan demikian, kredibilitas pesan di media sosial tidak menjamin terjadinya perubahan perilaku khalayak dalam mengadopsi informasi kesehatan yang ada.

Pada penelitian yang dilakukan oleh peneliti terhadap mahasiswa aktif Fikom Unpad, terdapat hasil analisis korelasional dari setiap indikator. Hasil analisis yang peneliti lakukan menyatakan bahwa terdapat hubungan intensitas terpaan Twitter dan kredibilitas pesan
Tabel 4 Analisis Uji Pearson Kredibilitas (X2) terhadap Perilaku (Y2)

\begin{tabular}{ccc}
\hline \multicolumn{2}{c}{ Correlation } & Perilaku \\
\hline Intensitas & Pearson & .023 \\
& Correlation & \\
& Sig. (2-tailed) & .799 \\
$\mathrm{~N}$ & 120 \\
\hline Sumber: Hasil Olah Data Penelitian (2020)
\end{tabular}

dengan perubahan sikap kesehatan mahasiswa. Sebaliknya, terpaan Twitter dan kredibilitas pesan tidak memiliki hubungan dengan perubahan perilaku kesehatan mahasiswa.

Dalam hasil analisis korelasional, variabel intensitas terpaan Twitter (X1) dan kredibilitas pesan (X2) terhadap variabel sikap kesehatan mahasiswa (Y1), masing-masing memiliki nilai korelasi sebesar $r=0.287$ (X1Y1) dan 0.405 (X2Y1). Karena koefisien memiliki nilai yang lebih besar dari $p=0.05$, maka intensitas dan kredibilitas pesan memiliki hubungan dengan sikap kesehatan mahasiswa.

Variabel intensitas (X1) dan kredibilitas (X2) terhadap variabel perilaku (Y2), masing-masing koefisien bernilai $r=0.082$ (X1Y2) dan $r=0.023$ (X2Y2). Nilai korelasi ini tidak signifikan karena keduanya memiliki nilai signifikansi. (2-tailed) yang lebih besar dari 0.05 atau 0.01. Variabel intensitas dan kredibilitas tidak memiliki hubungan dengan perilaku kesehatan mahasiswa.

Peneliti menggunakan teori kognitif respon dari Aaker dan Myers pada 1987 yang memiliki asumsi bahwa khalayak merupakan bagian dari suatu proses penerimaan informasi dari media yang berperan secara aktif mengevaluasi pesanpesan yang diterima dengan berdasarkan pada wawasan, pengetahuan, serta sikap yang telah dimiliki (Shen, 2020). Perubahan yang terjadi akibat proses tersebut selanjutnya mengarah pada terjadinya perubahan sikap. Berdasarkan Cognitive Response Theory, terdapat beberapa proses yang harus dialami individu untuk mencapai adanya perubahan sikap. Proses tersebut diawali dengan terpaan informasi yang 
diterima penerima pesan (ad exposure) hingga memasuki ranah kesadaran, pengetahuan, dan pemahamannya (cognitive response). Perubahan kognisi yang terjadi pada penerima pesan selanjutnya menyebabkan perubahan perilaku yang dianalisis lebih lanjut menggunakan Teori Elaboration Likelihood Model (ELM).

Teori Elaboration Likelihood Model (ELM) adalah teori yang biasa digunakan dalam komunikasi persuasif untuk mengamati perubahan sikap dan perilaku (Petty \& Briñol, 2012). Elaborasi mengacu pada sejauh mana individu berpikir atau secara mental mengubah argumen yang terkandung dalam komunikasi. Likelihood, mengacu pada probabilitas suatu peristiwa akan terjadi, digunakan untuk menunjukkan fakta bahwa elaborasi bisa jadi mungkin atau tidak mungkin. ELM menetapkan bahwa ada dua cara berbeda orang memproses komunikasi. Ini disebut rute, yang menunjukkan bahwa dua jalan raya yang berbeda melintasi pikiran, membawa pikiran dan reaksi ke pesan. ELM mengacu pada dua rute menuju persuasi, yaitu rute sentral dan rute periferal.

Rute Sentral, ditandai dengan elaborasi kognitif yang cukup besar. Ketika orang memproses informasi secara terpusat, hati-hati mengevaluasi argumen pesan, merenungkan implikasi dari ide komunikator, dan menghubungkan informasi dengan pengetahuan, bias, dan nilai mereka sendiri. Ini adalah jalan orang yang berpikir menuju persuasi. Perubahan sikap akibat pemikiran yang mendalam melalui rute ini cenderung bertahan lebih lama ketimbang perubahaan yang terbentuk melalui rute pemikiran periferal (O'keefe, 2015). Proses ini biasa dilakukan ketika seseorang ingin membuat keputusan yang cukup krusial seperti menentukan sikap dan perilaku kesehatannya. Khalayak yang fokus pada pencegahan dan penanganan penyakit lebih memperhatikan argumen dan informasi mengenai kesehatan dibandingkan informasi yang ia temukan lainnya. Berbeda dengan rute sentral, rute periferal mengizinkan orang-orang untuk memeriksa pesan secara cepat dan fokus pada isyarat sederhana untuk membantu mereka membuat keputusan.

ELM adalah sebuah teori yang dikemukakan oleh Petty dan Cacioppo lebih dari 30 tahun yang lalu. Banyak akademisi yang telah mempelajari ELM dengan lebih dalam, dan juga memuji teori ini; namun teori ini juga menuai banyak diskusi, debat, kritik dan juga peleburan dengan ideide baru seiring berjalannya waktu. Teori ELM berpendapat bahwa, secara teoritis, variabel tertentu dapat berfungsi dalam salah satu dari berbagai kapasitas. ELM juga dapat dipaparkan dalam pandangan peran kredibilitas sebuah sumber. Kredibilitas dapat menimbulkan fungsi ganda, berdasarkan elaboration likelihood yang ada. Sebagai contoh, keahlian seorang ilmuwan dapat berfungsi sebagai peripheral cue untuk orang yang tidak paham atau peduli terhadap masalah lingkungan. Bagi orang yang memiliki pengetahuan yang lebih, pandangan sang ilmuwan dapat berfungsi sebagai sebuah argumen. Selebihnya, bagi individu lainnya yang memiliki pengetahuan yang cukup tentang lingkungan dapat menstimulasi gagasan yang relevan dengan isu tersebut.

Teori ELM dan cognitive response telah membuktikan alasan dari pengaruh intensitas dan kredibilitas pesan terhadap perubahan sikap seseorang. Sementara perubahan perilaku memiliki dimensi yang lebih kompleks dari kedua faktor itu, seperti dengan yang dijelaskan dalam Teori Perilaku Terencana atau Theory of Planned Behavior (TPB). Teori Perilaku Terencana pertama kali dikemukakan oleh Icek Ajzen, teori ini memberikan gagasan bahwa intensi perilaku seseorang dapat diukur oleh tiga komponen utama, yaitu sikap, norma subjektif, dan kontrol perilaku persepsi (Ajzen, 2020). 
Berdasarkan teori ini, sikap dapat diartikan sebagai perasaan seseorang terhadap suatu hal. Norma subjektif adalah keyakinan akan adanya harapan banyak orang terhadap dirinya, teori ini menyatakan bahwa pandangan orang lain terhadap suatu hal akan mempengaruhi minat seseorang untuk melakukan suatu perilaku. Norma subjektif berasal dari lingkungan sekitar, seperti keluarga, teman, atau bahkan masyarakat yang menyampaikan pendapatnya melalui media sosial. Jika dikaitkan dengan penelitian ini, faktor yang mempengaruhi perilaku seseorang bukanlah intensitas penggunaan Twitter sendiri, melainkan pesan-pesan serta pendapat yang disampaikan oleh orang-orang penting (keluarga, teman, rekan) di Twitter. Ketika individu melihat banyak orang penting mengharapkan dirinya untuk melakukan perilaku kesehatan tertentu, individu tersebut akan terdorong untuk mengikuti perilaku tersebut (Ajzen, 2015).

Persepsi kontrol perilaku atau kontrol perilaku adalah perasaan seseorang mengenai mudah atau sulitnya mewujudkan suatu perilaku tertentu, dengan dimensi keyakinan diri, dukungan pemerintah, dan dukungan teknologi. Informasi kesehatan yang diberikan dalam Twitter menciptakan suatu kontrol perilaku dalam diri audiens, dimana audiens akan membentuk keyakinan diri yang dipengaruhi oleh informasi yang ditemui di Twitter tersebut. Pada dasarnya, informasi tersebut didukung oleh perkembangan teknologi, yang kemudian memberikan aplikasi pengetahuan yang diambil ke dalam suatu perilaku kesehatan. Penelitian ini menemukan bahwa terdapat hubungan antara intensitas penggunaan serta kredibilitas pesan yang disampaikan dengan perubahan sikap kesehatan mahasiswa.

Penelitian ini menemukan 4 hal. Pertama, terdapat hubungan antara intensitas pengguna Twitter di saat pandemi COVID-19 dengan sikap kesehatan mahasiswa. Kedua, terdapat hubungan antara kredibilitas pesan di Twitter dengan sikap kesehatan mahasiswa. Ketiga, tidak terdapat korelasi antara intensitas terpaan Twitter dengan perilaku. Keempat, terdapat hubungan antara intensitas terpaan Twitter dan kredibilitas pesan dengan perubahan sikap kesehatan mahasiswa.
Penelitian ini berkontribusi untuk merekomendasikan terkait penggunaan media sosial Twitter terhadap penyebaran informasi kesehatan dalam situasi krisis dan risiko, seperti pandemi COVID-19. Penyebaran pesan informasi kesehatan melalui media sosial Twitter dinilai cukup positif pada mahasiswa. Informasi Twitter yang diterima dapat memengaruhi sikap dengan syarat berupa kredibilitas pesan dan intensitas pesan yang diterima.

Peneliti menemukan beberapa hambatan dalam melakukan penelitian, di antaranya adalah jumlah penelitian sebelumnya dengan topik terkait yang relatif sedikit, serta kurangnya representasi umur yang beragam pada mahasiswa yang menjadi responden dalam penelitian. Peneliti berharap lebih banyak penelitian selanjutnya yang berfokus pada mahasiswa dengan menampilkan rentang umur beragam, serta membahas secara spesifik mengenai aspek-aspek yang memengaruhi efek media sosial Twitter terhadap sikap serta perilaku kesehatan mahasiswa.

Penggunaan media tidak memiliki pengaruh, juga tidak berhubungan, dengan perilaku kesehatan pada diri mahasiswa. Sikap pada dasarnya dapat memprediksi perilaku, namun dalam penelitian ini ditemukan bahwa meskipun terpaan Twitter berpengaruh terhadap pengadopsian sikap kesehatan mahasiswa, sikap ini tidak berlanjut ke tahap perubahan perilaku kesehatan.

Tidak adanya kesinambungan antara sikap dan perilaku kesehatan berkaitan dengan Teori TPB, dimana perilaku seseorang diukur melalui faktor-faktor sikap, norma subjektif, dan kontrol perilaku. Berdasarkan faktor norma subjektif, dimana pandangan orang lain terhadap suatu informasi memengaruhi minatnya untuk mengaplikasikan suatu perilaku, sikap kesehatan tidak akan menyebabkan suatu perilaku yang berkelanjutan ketika tindakan yang diimplementasikan tidak mendapatkan pengakuan dalam pandangan masyarakat. 
Adanya faktor persepsi kontrol perilaku atau kontrol perilaku turut menjadi faktor yang menentukan ada atau tidaknya hubungan dalam implementasi perilaku kesehatan manusia yang diaplikasikan dari informasi kesehatan di Twitter. Faktor ini menjadi eksplanasi bagi tingkat kemudahan maupun kesulitan dalam mewujudkan suatu perilaku tertentu, yang dipengaruhi oleh sejauh mana individu memiliki keyakinan diri untuk melakukan perilaku yang berdasarkan sikapnya. Faktor ini juga mendasarkan pada dukungan pemerintah serta dukungan teknologi sebagai bagian dari penyebab implementasi perilaku. Ketika seseorang memiliki keyakinan diri yang cukup untuk mengaplikasikan informasi kesehatan yang ditemukan dalam Twitter menjadi sikap dan kemudian menjadikannya sebagai penerapan dalam kehidupan sehari-hari, maka suatu perilaku kesehatan akan terbentuk. Sebaliknya, ketika seseorang merasa bahwa dirinya tidak memiliki keyakinan yang cukup terhadap informasi yang dipaparkan terhadapnya serta sikap yang sebelumnya telah diterapkan, ditambah dengan kurangnya dukungan terhadap informasi kesehatan di Twitter oleh pemerintah dari sisi kredibilitas, hal ini menimbulkan tidak adanya pengimplementasian perilaku kesehatan.

\section{Simpulan}

Penelitian ini menemukan empat temuan. Pertama, terdapat hubungan antara intensitas pengguna Twitter di saat pandemi COVID-19 dengan sikap kesehatan mahasiswa. kedua, terdapat hubungan antara kredibilitas pesan di Twitter dengan sikap kesehatan mahasiswa. Ketiga, tidak terdapat ada korelasi antara hubungan intensi dengan perilaku. Keempat, terdapat hubungan intensitas terpaan Twitter dan kredibilitas pesan dengan perubahan sikap kesehatan mahasiswa.

Penelitian memberikan berkontribusi merekomendasikan kepada pihak-pihak berkepentingan terkait penggunaan media sosial Twitter untuk penyebaran informasi kesehatan dalam situasi krisis dan risiko, seperti pandemi COVID-19. Penyebaran pesan informasi kesehatan melalui media sosial Twitter dinilai cukup positif pada mahasiswa. Informasi Twitter yang diterima dapat memengaruhi sikap dengan syarat berupa kredibilitas pesan dan intensitas pesan yang diterima dapat terpenuhi.

Peneliti menemukan beberapa hambatan dalam melakukan penelitian, di antaranya adalah jumlahpenelitian sebelumnya dengantopikterkait yang relatif sedikit, serta kurangnya representasi umur yang beragam pada mahasiswa yang menjadi responden dalam penelitian. Peneliti berharap lebih banyak penelitian selanjutnya yang berfokus pada mahasiswa dengan menampilkan rentang umur beragam, serta membahas secara spesifik mengenai aspek-aspek yang memengaruhi efek media sosial Twitter terhadap sikap serta perilaku kesehatan mahasiswa.

\section{Ucapan Terima Kasih}

Peneliti mengucapkan terima kasih kepada Bapak S. Kunto Adi Wibowo, M.Comn., Ph.D dan Bapak Ikhsan Fuady, S.P., M.Si. selaku dosen mata kuliah Metode Survey pada program studi Ilmu Komunikasi Universitas Padjadjaran atas bimbingan dan saran yang diberikan sebagai arahan jalannya penelitian. Peneliti juga mengucapkan terima kasih kepada responden penelitian yang telah meluangkan waktu untuk mengisi kuesioner, serta pihak-pihak lainnya yang berpartisipasi dalam penelitian ini.

\section{Daftar Pustaka}

Aditya, N. R. (2021). Kemenkominfo: Sejak Pandemi Ada 1.387 Hoaks, 134 Diproses Polisi. https://nasional.kompas.com/ $\mathrm{read} / 2021 / 01 / 27 / 10394341 /$ kemenkominfosejak-pandemi-ada-1387-hoaks-134diproses-polisi?page $=$ all

Ahmad, A. R., \& Murad, H. R. (2020). The impact of social media on panic during the COVID-19 pandemic in Iraqi Kurdistan: online questionnaire study. Journal of Medical Internet Research, 22(5), e19556. 
Ajzen, I. (2015). The theory of planned behaviour is alive and well, and not ready to retire: a commentary on Sniehotta, Presseau, and Araújo-Soares. Health Psychology Review, 9(2), 131-137.

Ajzen, I. (2020). The theory of planned behavior: Frequently asked questions. Human Behavior and Emerging Technologies, 2(4), 314-324.

Al-Dmour, H., Salman, A., Abuhashesh, M., \& Al-Dmour, R. (2020). Influence of social media platforms on public health protection against the COVID-19 pandemic via the mediating effects of public health awareness and behavioral changes: integrated model. Journal of Medical Internet Research, 22(8), e19996.

Ali, S., Khalid, A., \& Zahid, E. (2021). Is CoViD-19 immune to misinformation? A brief overview. Asian Bioethics Review, $1-23$.

Alibali, M. W., Brown, S. A., \& Menendez, D. (2019). Understanding strategy change: Contextual, individual, and metacognitive factors. Advances in Child Development and Behavior, 56, 227-256.

Appelman, A., \& Sundar, S. S. (2016). Measuring message credibility: Construction and validation of an exclusive scale. Journalism \& Mass Communication Quarterly, 93(1), 59-79.

Bernasconi, F. (2020). Fontana: "Il coronavirus è poco più di una normale influenza" ilGiornale. https://www.ilgiornale.it/news/ politica/fontana-coronavirus-poco-pinormale-influenza-1831891.html

Boer, M., Stevens, G. W. J. M., Finkenauer, C., de Looze, M. E., \& van den Eijnden, R. J. J. M. (2021). Social media use intensity, social mediause problems, and mental health among adolescents: Investigating directionality and mediating processes. Computers in Human Behavior, 116, 106645.
Bramasta, D. B. (2021). UPDATE Corona 1 September: Kasus Aktif Indonesia Turun di Bawah 200. https://www.kompas.com/tren/ $\mathrm{read} / 2021 / 09 / 01 / 074500965 /$ update-corona1-september--kasus-aktif-indonesia-turundi-bawah-200.000

Bromme, R., \& Goldman, S. R. (2014). The public's bounded understanding of science. Educational Psychologist, 49(2), 59-69.

Brooks, I. (2020). Analysis of Social Media Data about COVID-19 in the Americas Twitter Volume 03 / 2020.

Chen, Y.-Y., Li, C.-M., Liang, J.-C., \& Tsai, C.C. (2018). Health information obtained from the internet and changes in medical decision making: questionnaire development and cross-sectional survey. Journal of Medical Internet Research, 20(2), e47.

Cook, J., Lewandowsky, S., \& Ecker, U. K. H. (2017). Neutralizing misinformation through inoculation: Exposing misleading argumentation techniques reduces their influence. PloS One, 12(5), e0175799.

Depoux, A., Martin, S., Karafillakis, E., Preet, R., Wilder-Smith, A., \& Larson, H. (2020). The pandemic of social media panic travels faster than the COVID-19 outbreak. Oxford University Press.

Dzulfaroh, A. N. (2020). Virus Corona Jadi Pandemi Global, Apa Dampak dan Langkah Selanjutnya? In Kompas. com. https://www.kompas.com/tren/ $\mathrm{read} / 2020 / 03 / 12 / 064800265 /$ virus-coronajadi-pandemi-global-apa-dampak-danlangkah-selanjutnya-

Farida, I. A., Suminar, D. R., \& Nawangsari, N. A. F. (2018). ADAPTASI BAHASA DAN BUDAYA NEED FOR COGNITION SCALE. Jurnal Sains Psikologi, 7(2), 148154.

Flemming, D., Cress, U., \& Kimmerle, J. (2017). Processing the scientific tentativeness of medical research: an experimental study on the effects of research news and user comments in online media. Science Communication, 39(6), 745-770. 
Gao, J., Zheng, P., Jia, Y., Chen, H., Mao, Y., Chen, S., Wang, Y., Fu, H., \& Dai, J. (2020). Mental health problems and social media exposure during COVID-19 outbreak. Plos One, 15(4), e0231924.

Gharavi, E., Nazemi, N., \& Dadgostari, F. (2020). Early outbreak detection for proactive crisis management using twitter data: Covid-19 a case study in the us. ArXiv Preprint ArXiv:2005.00475.

Gottlieb, M., \& Dyer, S. (2020). Information and Disinformation: Social Media in the COVID-19 Crisis. Academic Emergency Medicine.

Gupta, L., Gasparyan, A. Y., Misra, D. P., Agarwal, V., Zimba, O., \& Yessirkepov, M. (2020). Information and misinformation on COVID-19: a cross-sectional survey study. Journal of Korean Medical Science, 35(27).

Indonesia.go.id. (2020). Kasus Covid-19 Pertama, Masyarakat Jangan Panik. file:/// Users/mairaphinata/Desktop/Dafpus Jurnal Metsur/Indonesia.go.id - Kasus Covid-19 Pertama, Masyarakat Jangan Panik.html

Kementerian Kesehatan Republik Indonesia. (2020). Vaksin Covid-19 Belum Ditemukan, Pemerintah Siapkan Skenario New Normal. https://www.kemkes.go.id/article/ view/20052900001/vaksin-covid-19-belumditemukan-pemerintah-siapkan-skenarionew-normal.html

Kementerian Komunikasi dan Informatika. (2020). Penggunaan Internet Naik 40\% Saat Bekerja dan Belajar dari Rumah.

Komite Penanganan Covid - 19 dan Pemulihan Ekonomi Nasional. (2020). Ketahui: Adaptasi Kebiasaan Baru - Apa yang Harus Kamu Ketahui? | Satgas Penanganan COVID-19. https://covid19.go.id/edukasi/ apa-yang-harus-kamu-ketahui-tentangcovid-19/adaptasi-kebiasaan-baru

Kor, P. P. K., Leung, A. Y. M., Parial, L. L., Wong, E. M. L., Dadaczynski, K., Okan, O., Amoah, P. A., Wang, S. S., Deng, R., \&
Cheung, T. C. C. (2021). Are People With Chronic Diseases Satisfied With the Online Health Information Related to COVID-19 During the Pandemic? Journal of Nursing Scholarship, 53(1), 75-86.

Kouzy, R., Abi Jaoude, J., Kraitem, A., El Alam, M. B., Karam, B., Adib, E., Zarka, J., Traboulsi, C., Akl, E. W., \& Baddour, K. (2020). Coronavirus goes viral: quantifying the COVID-19 misinformation epidemic on Twitter. Cureus, 12(3).

Lancet, T. (2020). COVID-19: fighting panic with information. Lancet (London, England), 395(10224), 537.

Maragakis, L. L. (2020). The New Normal and Coronavirus | Johns Hopkins Medicine. https://www.hopkinsmedicine.org/health/ conditions-and-diseases/coronavirus/ coronavirus-new-normal

McGowan, B. S., Wasko, M., Vartabedian, B. S., Miller, R. S., Freiherr, D. D., \& Abdolrasulnia, M. (2012). Understanding the factors that influence the adoption and meaningful use of social media by physicians to share medical information. Journal of Medical Internet Research, 14(5), e117.

Nasrullah, R. (2015). Media sosial: Perspektif komunikasi, budaya, dan sosioteknologi. Bandung: Simbiosa Rekatama Media, 2016, 2017.

Nurrezki, S., \& Irawan, R. (2020). Hubungan Stres, Cemas, dan Depresi dengan Kejadian Migrain Pada Mahasiswa Kedokteran di Jakarta. Damianus Journal of Medicine, 19(1), 1-7.

O'keefe, D. J. (2015). Persuasion: Theory and research. Sage Publications.

Pennycook, G., McPhetres, J., Zhang, Y., Lu, J. G., \& Rand, D. G. (2020). Fighting COVID-19 misinformation on social media: Experimental evidence for a scalable accuracy-nudge intervention. Psychological Science, 31(7), 770-780. 
Perloff, R. M. (2017). The dynamics of persuasion: Communication and attitudes in the 21 st century. In The Dynamics of Persuasion: Communication and Attitudes in the Twenty-First Century. https://doi. org/10.4324/9781315657714

Perrault, E. K., Hildenbrand, G. M., McCullock, S. P., Schmitz, K. J., \& Dolick, K. N. (2019). Hashtag health: College health on social media and students' motivations to follow, interact, and share their social media content. Health Promotion Practice, 20(5), 721-729.

Petrocchi, N., Asnaani, A., Martinez, A. P., Nadkarni, A., \& Hofmann, S. G. (2015). Differences between people who use only Facebook and those who use Facebook plus Twitter. International Journal of HumanComputer Interaction, 31(2), 157-165.

Petty, R. E., \& Briñol, P. (2012). The elaboration likelihood model. In Handbook of theories of social psychology, Vol. 1 (pp. 224245). Sage Publications Ltd. https://doi. org/10.4135/9781446249215.n12

Prybutok, G., \& Ryan, S. (2015). Social media: the key to health information access for 18-to 30-year-old college students. CIN: Computers, Informatics, Nursing, 33(4), 132-141.

Rong, X., Yang, L., Chu, H., \& Fan, M. (2020). Effect of delay in diagnosis on transmission of COVID-19. Math Biosci Eng, 17(3), 2725-2740.

Rosenberg, H., Syed, S., \& Rezaie, S. (2020). The Twitter pandemic: The critical role of Twitter in the dissemination of medical information and misinformation during the COVID-19 pandemic. Canadian Journal of Emergency Medicine, 22(4), 418-421.

Rosini, R., \& Nurningsih, S. (2018). Pemanfaatan media sosial untuk pencarian dan komunikasi informasi kesehatan. Berkala Ilmu Perpustakaan Dan Informasi, 14(2), 226-237.
Sciences, R. (2020). Twitter Functions in COVID-19 Pandemic and Other Natural Disasters: A Systematic Review Hamed Seddighi, Ibrahim Salmani. August. https:// doi.org/10.20944/preprints202008.0235.v1

Seddighi, H., Seddighi, S., Salmani, I., \& Sedeh, M. S. (2021). Public-private-people partnerships (4P) for improving the response to COVID-19 in Iran. Disaster Medicine and Public Health Preparedness, 15(1), e44-e49.

Shen, L. (2020). Cognitive Response Theory. The International Encyclopedia of Media Psychology, 1-5.

Shi, J., Poorisat, T., \& Salmon, C. T. (2018). The use of social networking sites (SNSs) in health communication campaigns: review and recommendations. Health Communication, 33(1), 49-56.

St Louis, C., \& Zorlu, G. (2012). Can Twitter predict disease outbreaks? Bmj, 344.

Stojanovic, I., Andreu, L., \& Curras-Perez, R. (2018). Effects of the intensity of use of social media on brand equity: An empirical study in a tourist destination. European Journal of Management and Business Economics.

Stoycheff, E., Liu, J., Wibowo, K. A., \& Nanni, D. P. (2017). What have we learned about social media by studying Facebook? A decade in review. New Media \& Society, 19(6), 968-980.

Strekalova, Y. A. (2017). Health risk information engagement and amplification on social media: News about an emerging pandemic on Facebook. Health Education \& Behavior, 44(2), 332-339.

Tagliabue, F., Galassi, L., \& Mariani, P. (2020). The "pandemic" of disinformation in COVID-19. SN Comprehensive Clinical Medicine, 2(9), 1287-1289.

Van Lange, P. A. M., Kruglanski, A. W., \& Higgins, E. T. (2011). Handbook of theories of social psychology: Volume two (Vol. 2). SAGE publications. 
Venegas-Vera, A. V., Colbert, G. B., \& Lerma, E. V. (2020). Positive and negative impact of social media in the COVID-19 era. Reviews in Cardiovascular Medicine, 21(4), 561564.

VOI Indonesia. (2021). Selama Pandemi, Pengguna Twitter Tumbuh Pesat. https:// voi.id/teknologi/48500/selama-pandemipengguna-twitter-tumbuh-pesat

Wang, Q., Chen, W., \& Liang, Y. (2011). The effects of social media on college students. MBA Student Scholarship, 5(13), 13791548.

Washington Post. (2020). Twitter sees record number of users during pandemic, but advertising sales slow - The Washington Post. https://www.washingtonpost.com/business/ economy/twitter-sees-record-number-ofusers-during-pandemic-but-advertisingsales-slow/2020/04/30/747ef0fe-8ad8-11ea9dfd-990f9dcc71fc_story.html

Wheaton, M. G., Prikhidko, A., \& Messner, G. R. (2021). Is fear of COVID-19 contagious? The effects of emotion contagion and social media use on anxiety in response to the coronavirus pandemic. Frontiers in Psychology, 11, 3594.

WHO. (2020a). Coronavirus. https://www.who. int/health-topics/coronavirus\#tab=tab_1

WHO. (2020b). Naming the coronavirus disease (COVID-19) and the virus that causes it. https://www.who.int/emergencies/diseases/ novel-coronavirus-2019/technical-guidance/ naming-the-coronavirus-disease-(covid2019)-and-the-virus-that-causes-it

Wirtz, B. W., Göttel, V., \& Daiser, P. (2017). Social networks: usage intensity and effects on personalized advertising. Journal of Electronic Commerce Research, 18(2), 103123.

Zhang, A. X., Ranganathan, A., Metz, S. E., Appling, S., Sehat, C. M., Gilmore, N., Adams, N. B., Vincent, E., Lee, J., \& Robbins, M. (2018). A structured response to misinformation: Defining and annotating credibility indicators in news articles. Companion Proceedings of the The Web Conference 2018, 603-612. 